\title{
Protease Production and Enzymatic Soaking of Salt-Preserved Buffalo Hides for Leather Processing
}

SHORT COMMUNICATION

V.P. Zambare, S.S. Nilegaonkar*, P.P. Kanekar

Microbial Sciences Division, Agharkar Research Institute, Pune-411004 INDIA

\begin{abstract}
Response surface methodological (RSM) optimization of protease by Pseudomonas aeruginosa MCM B327, increased 1.3 fold activity with $1 \%$ inoculum having cell density of $27.57 \times 10^{9}$ cells $\mathrm{mL}^{-1}$ at $\mathrm{pH} 7,30^{\circ} \mathrm{C}$ and $72 \mathrm{~h}$ of incubation. Protease enzyme recovered from $P$. aeruginosa showed characteristic activities against diverse proteins of hide. Enzyme was found to be active with substrates e.g. casein, Bovine serum albumin, gelatin, elastin, haemoglobin but inactive against keratin and collagen. During leather manufacturing, non-collagenase and non-keratinase activities have advantageous in a quality leather and hair saving process, respectively. Increased proteolytic enzyme concentration (0.1-0.5\%) in soaking process showed increased water penetration because of hydrolysis of albumin and elastin proteins as indicated by opened fibers in histopathological sections. These findings suggest, protease secreted by $P$. aeruginosa may have application in soaking operation of leather processing for minimizing harmful deharing chemicals and processing time.
\end{abstract}

\section{Received on: 17 Nov. 2012}

Accepted on: 8 Jan. 2013

Published on: 13 Jan. 2014

DOI: $10.5195 /$ iioablett.2013.19

\section{INTRODUCTION}

Proteases can be obtained from different sources such as bacteria, fungi, or certain insects. In order to obtain commercially viable yields of protease it is essential to optimize cultivation media for the growth of organism and production of protease. Proteases have several applications in detergent, pharmaceuticals, foods, beverages and leather industries. Various statistical methods such as response surface methodology (RSM), central composite design (CCD), artificial neural network (ANN) models were used for optimization of protease production by many researchers (Puri et al. 2002; Dutta et al. 2005; Rao et al. 2006; Saxena and Singh, 2010).

Leather sector has offered unique advantages in terms of raw material resources, manufacturing capacity, expertise and knowledge base employment and export potential (Luthra, 2006). Leather is a byproduct of meat industry and is prepared from heterogeneous fibrous mass of animal skins/ hides. It has been reported that chemical composition of skins and hides vary from species to species as well as their locations (Muthian et al. 1968). Animal skin/ hides are biological matrix significantly loaded with approx. $33 \%$ protein and approx. $2 \%$ of fat or triglycerides (Sharphouse, 1983).
Due to advancement in meat industries and meat demand, animal skin production was more and needed to preserve it. Traditionally, common salt (30-40\%) is used for skin/ hides preservations.

Leather is a stabilized collagen product and has different leather processing steps are shown in Figure 1. Beamhouse operations are very important to produce high quality leather. Traditional chemical leather processing generates huge amount of environmental pollutions (Thanikaivelan et al. 2004; Kanagraj et al. 2006). Whereas, enzyme biocatalysts were found to be effective in soaking, dehairing, bating and degreasing operations of environmental friendly leather processing.

Soaking is the removal of globular proteins, dirt, dung, blood and salts. Protease produced from Aspergillus flavus, A. parasiticus, A. oryzae, and Bacillus subtilis were reported for soaking of animal skins. Some amylolytic enzymes from $A$. awamori were also showing soaking application (Kamini et al., 1999). A soaking method using proteolytic enzymes and carbohydrases in the $\mathrm{pH}$ range of 5.5 to 10 has been described by Kamini et al. (1999). Soaking enzymes are available in market but in literature very limited reports are available. Thus, this paper focuses on the production of bacterial protease 
and its use in soaking of buffalo hide for quality leather and its substrate specific characterization.

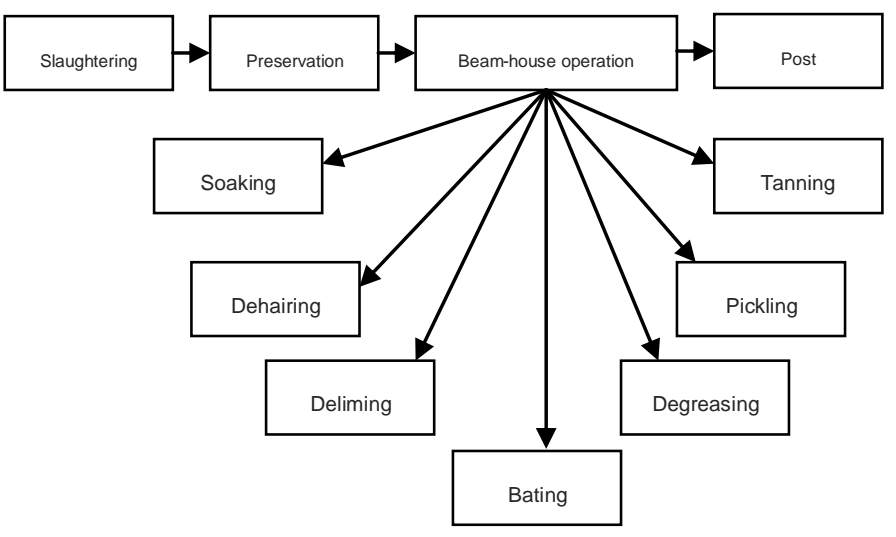

Figure 1. Leather processing steps.

\section{MATERIALS AND METHODS}

\section{Chemicals and Substrates}

All chemicals and reagents of analytical grade were used. All types of substrates, like casein, BSA, gelatin, elastin-orcein, collagen, and keratin azure were purchased from Sigma Chemicals (St. Louis, MO, USA). The buffalo hide was obtained from Local Municipal Corporation Slaughterhouse (Pune, India).

\section{Factorial Design for Protease Production}

Our previous publication showed soybean mealtryptone (ST) as best medium (Zambare et al., 2011). In this study the optimum concentrations of soybean meal and tryptone were obtained by non-linear factorial design and RSM. The experiment of different run was conducted in $250 \mathrm{~mL}$ Erlenmeyer flasks containing 100 $\mathrm{mL}$ of ST medium inoculated with the freshly prepared $1 \% \mathrm{v} / \mathrm{v}$ inoculums ( $24 \mathrm{~h}$ grown in Nutrient broth) and incubated for $72 \mathrm{~h}$ with $150 \mathrm{rpm}$ at $30^{\circ} \mathrm{C}$. After cultivation, the cell-free supernatant was obtained by centrifugation at $10,000 \mathrm{rpm}$ and the extracellular protease activity (caseinolytic) of the fermented broth was determined. In the next stage RSM was used to study the interactive effects of two variables, i.e. soybean meal and tryptone for improving the protease activity. Each factor in the factorial design was studied at four different concentrations (0.5- 2.0\%). The experiment was conducted in duplicate. This design is represented by second-order polynomial regression model, Equation (1) for the predicted activity of the enzyme as:

Predicted activity $=\beta_{0}+\beta_{1} X+\beta_{2} Y+\beta_{3} X Y+\beta_{4} X X+$
$\beta_{5} Y Y$

Where, $X$ - coded variable for soybean meal, $Y$ coded variable for tryptone and $\boldsymbol{\beta}_{0,} \boldsymbol{\beta}_{1}, \boldsymbol{\beta}_{2}, \boldsymbol{\beta}_{3}, \boldsymbol{\beta}_{4}, \boldsymbol{\beta}_{5}$ are coefficients for their respective variables.

\section{Enzyme Preparation and Partial Purification}

The protease was produced in ST medium $(\mathrm{pH} 7.0)$ at $30^{\circ} \mathrm{C}$ under shake culture condition $(150 \mathrm{rpm})$ with $1 \%$ inoculum. The cell growth was measured at $600 \mathrm{~nm}$. Cell free supernatants were analyzed for enzyme activity at 3 $\mathrm{h}$ interval up to $96 \mathrm{~h}$. The cell free supernatant (CFS) was obtained by centrifugation and the proteolytic activity was measured on different substrates. The enzyme from CFS was partially purified by ammonium sulphate precipitation at $60 \%$ saturation followed by overnight dialysis against Tris- $\mathrm{HCl}$ buffer $(\mathrm{pH} 8)$ under cold condition at $4{ }^{\circ} \mathrm{C}$. This precipitate was used for substrate specificities and soaking application of leather processing at laboratory scale.

\section{Enzyme Assays}

\section{Protease}

Protease activity was measured using caseinolytic assay (Zambare et al. 2011a). The culture supernatant (1 mL) was incubated in $4 \mathrm{~mL}$ of $0.625 \%$ casein (Tris- $\mathrm{HCl}$ buffer, $\mathrm{pH} 8.0$ ) at $35^{\circ} \mathrm{C}$ for $30 \mathrm{~min}$. The reaction was stopped by the addition of $5 \mathrm{~mL}$ of trichloroacetic acid (5\%) and the casein hydrolysis product was measured by modified Folin-Ciocalteu method, against inactive enzyme at $660 \mathrm{~nm}$. A standard graph was generated using standard tyrosine of $10-50 \mu \mathrm{g} \mathrm{mL}-1$. One unit $(\mathrm{U})$ of protease activity was defined as the amount of enzyme, which liberated $1 \mu \mathrm{g}$ tyrosine per min at $35^{\circ} \mathrm{C}$.

\section{Albuminase}

The albuminase activity was determined according to protease assay as described above with Bovine Serum Albumin (BSA) as a substrate. One unit (U) of albuminase activity was defined as the amount of enzyme, which liberated $1 \mu \mathrm{g}$ tyrosine per min at $35^{\circ} \mathrm{C}$. 


\section{Elastase}

Elastin-orcein assay was used to determine $\mathrm{d}$ elastase activity using method described by Sachar et al. (1995). Twenty mg of elastin- orcein substrate was incubated with $0.5 \mathrm{~mL}$ of suitably diluted enzyme in $20 \mathrm{~mL}$ of Tris$\mathrm{HCl}$ buffer $\left(\mathrm{pH} 8.0\right.$ ) at $37^{\circ} \mathrm{C}$ for $20 \mathrm{~min}$. $2.5 \mathrm{~mL}$ of $0.7 \mathrm{M}$ phosphate buffer of $\mathrm{pH} 7.0$ was added. The mixture was centrifuged and the absorbance of the supernatant was read at $578 \mathrm{~nm}$. One unit of activity was defined as the amount of enzyme hydrolyzes $1 \mathrm{mg}$ of substrate per min at $37^{\circ} \mathrm{C}$.

\section{Keratinase}

Keratinase activity was determined using keratin azure as substrate (Takami et al. 1990). The cell free supernatant $(1 \mathrm{~mL})$ was mixed with $4 \mathrm{mg}$ keratin azure in $1 \mathrm{~mL}$ of Tris- $\mathrm{HCl}$ buffer ( $\mathrm{pH} 8.0$ ) incubated at $37^{\circ} \mathrm{C}$ for $60 \mathrm{~min}$. The reaction was stopped by centrifugation. The absorbance of supernatant was read at 595nm. One unit of activity was defined as the amount of enzyme, which increased absorbance by 0.001 under standard assay conditions.

\section{Collagenase}

The collagenase activity on collagen substrate was determined as described by Woessner (1961). $2 \mathrm{~mL}$ of collagen solution ( $\left.1 \mathrm{mg} \mathrm{mL}^{-1}\right)$ was prepared in Tris- $\mathrm{HCl}$, $\mathrm{pH} 8.0$, to that $0.5 \mathrm{~mL}$ of suitably diluted enzyme was added and incubated at $37^{\circ} \mathrm{C}$ for $1 \mathrm{~h}$. The reaction mixture was filtered through Whatmann filter No. 1. One $\mathrm{mL}$ of $0.05 \mathrm{M}$ chloramine-T was added to the filtrate and incubated at room temperature for $20 \mathrm{~min}$. To this $1.0 \mathrm{~mL}$ of $3.15 \mathrm{M}$ perchloric acid was added. After 5 minute, $1.0 \mathrm{~mL}$ of freshly prepared $20 \%$ solution of $p$ dimethyl amino benzaldehyde was added, and incubated at $60^{\circ} \mathrm{C}$ for $30 \mathrm{~min}$. The pink color developed was read at 557nm against blank containing distilled water instead of enzyme solution. A standard graph was generated using standard hydroxyproline solutions of 1 $10 \mu \mathrm{gmL}^{-1}$. One unit of activity was defined as the amount of enzyme, which liberated $1 \mu \mathrm{g}$ hydroxyproline per min at $37^{\circ} \mathrm{C}$

\section{Hemoglobin hydrolysis}

Hemoglobin hydrolysis assay was determined using method described by Sarath et al. (1996). Five milliliter haemoglobin substrate (2\%) was incubated with $1 \mathrm{ml}$ of enzyme solution at $35^{\circ} \mathrm{C}$ for $20 \mathrm{~min}$. The reaction was stopped by addition of $10 \mathrm{~mL}, 5 \%$ trichloroacetic acid and kept for $10 \mathrm{~min}$ at same temperature. The assay mixture was centrifuged and the supernatant was read at $280 \mathrm{~nm}$ against inactive enzyme as blank. One haemoglobin hydrolysis unit (HHU) was defined as the amount of enzyme, which increase the absorbance at 280nm under assay conditions.

\section{Enzymatic Soaking}

Salt preserved buffalo hide cut into pieces of approximate $35 \mathrm{gm}(10 \mathrm{~cm} \times 10 \mathrm{~cm}$ size $)$ and was used for enzymatic soaking studies. Soaking was carried out in $300 \%$ water (with $0.05 \%$ benzoic acid as preservative) and different concentrations of protease from $P$. aeruginosa $(0.1,0.3$ and $0.5 \% \mathrm{w} / \mathrm{w}$ of hide) with only water as a control. This soaking experiment was performed at room temperature. All pieces were observed periodically (up to 18h) for its looseness, water holding capacity and hair loosening. The soaked pieces were dehaired with conventional chemical dehairing with $10 \%$ lime, 2.5\% sodium sulphide and 20\% water (Raju et al., 1996). Dehaired pelts were washed and fixed in $10 \%(\mathrm{v} / \mathrm{v})$ formaldehyde for histopathalogical analysis.

\section{Enzymatic Soaking}

The pelts were dehydrated with 80, 95 and 100\% (v/v) of alcohol gradients followed by xylene treatment, and embedded in paraffin. Longitudinal sections (L.S.) of hide embedded in paraffin wax were obtained using a microtome. The sections were fixed on slides using starch paste containing thymol, which acts as a preservative. The sections were stained with Harris's haematoxylin stain followed by $0.5 \%$ (v/v) $\mathrm{HCl}$ and diluted ammonia (John and Merriline, 2002). The slides were observed microscopically (Labophot 2 microscope, Japan) for epidermis, hair root follicles, and corium (collagen layer).

\section{RESULTS AND DISCUSSIONS}

\section{Factorial Design for Protease Production}

Protease production using single factor is time consuming process and since last decade many reports are on protease production optimization using statistical experimental designs (Puri et al. 2002; Chauhan and Gupta, 2004). The experimental factorial design showed that both variables had significant effect on protease production. The observed response showed maximum protease activity of $389.42 \mathrm{UmL}^{-1}$ with $0.5 \%$ soybean meal and $1.5 \%$ tryptone which was in good agreement 
with predicted activity $373.76 \mathrm{UmL}^{-1}$ (Table 1). Overall Reddy et al. (2008) reported such protease production optimization by RSM.

From multiple linear regressions, the coefficients of the respective variables were calculated. The predicted response equation as shown below was obtained by adding the coefficients, concentrations of the variables in Equation 2.

\section{Protease activity $=113.836+117.291 X+271.734 Y-$ 34.491XY - 26.060XX - 77.305 YY

The larger the magnitudes of $t$-value smaller the $p$-value, the more significant is the corresponding coefficient. The significance level was tested by one-way ANOVA and found to be dependent upon tryptone concentration. The significance was $<0.05$ because the observed $F$ value was higher than the theoretical F value. The fisher F-test with a very low probability value demonstrated a very high significance for the regression model (Table 2). The goodness of fit of the model was checked by the determination coefficient $\left(\mathrm{R}^{2}\right)$. In this case, the value of the determination coefficient, $\mathrm{R}^{2}=0.684$, indicates that only $31.6 \%$ of the total variations are not explained by the model. The value of adjusted determination coefficient, Ad. $\mathrm{R}^{2}=0.525$, is moderate, which indicates a moderate significance ( $\mathrm{p}$ value $<0.05$ ) of the model (Adinarayana and Ellaiah, 2002). A higher value of the correlation coefficient, $\mathrm{R}=0.827$, signifies an excellent correlation between the independent variables. At the same time a relatively lower value of the coefficient of variation, $C V=17.3$, indicates improved precision and reliability of the conducted experiments (Adinarayana and Ellaiah, 2002).

Table 1. Observed responses and predicted values of protease activity

\begin{tabular}{|c|c|c|c|c|c|}
\hline \multirow{2}{*}{ Run } & \multicolumn{2}{|c|}{ Concentrations (\%) } & \multicolumn{2}{|c|}{ Protease activity $\left(\mathrm{U} \mathrm{mL}^{-1}\right)$} & \multirow{2}{*}{ Residual standard deviation } \\
\hline & Trytone & Soybean meal & Observed response & Predicted response & \\
\hline 1 & 0.5 & 0.5 & 243.3 & 273.885 & -1.154 \\
\hline 2 & 0.5 & 1.0 & 331.04 & 343.150 & -0.457 \\
\hline 3 & 0.5 & 1.5 & 389.42 & 373.763 & 0.591 \\
\hline 4 & 0.5 & 2.0 & 370.19 & 365.724 & 0.169 \\
\hline 5 & 1.0 & 0.5 & 354.22 & 304.362 & 1.881 \\
\hline 6 & 1.0 & 1.0 & 376.88 & 365.005 & 0.448 \\
\hline 7 & 1.0 & 1.5 & 386.16 & 386.995 & -0.032 \\
\hline 8 & 1.0 & 2.0 & 377.16 & 370.333 & 0.258 \\
\hline 9 & 1.5 & 0.5 & 320.05 & 321.810 & -0.066 \\
\hline 10 & 1.5 & 1.0 & 362.63 & 373.830 & -0.423 \\
\hline 11 & 1.5 & 1.5 & 370.87 & 387.198 & -0.616 \\
\hline 12 & 1.5 & 2.0 & 323.48 & 361.913 & -1.45 \\
\hline 13 & 2.0 & 0.5 & 309.05 & 326.228 & -0.648 \\
\hline 14 & 2.0 & 1.0 & 380.06 & 369.625 & 0.394 \\
\hline 15 & 2.0 & 1.5 & 376.88 & 374.370 & 0.095 \\
\hline 16 & 2.0 & 2.0 & 367.27 & 340.462 & 1.012 \\
\hline
\end{tabular}

Different \% concentrations of soybean meal and tryptone affected the protease activity (Figure 2). It was observed that the enzyme production increased with increase in tryptone concentration. On the other hand increase in soybean meal concentration had not increased the enzyme production. This suggested that, the enzyme 
production is induced when the medium is supplemented with tryptone.

Table 2. Analysis of variance (ANOVA) for factorial design.

\begin{tabular}{|lccccc|}
\hline SOV & SS & DF & MS & F value & p value \\
\hline Regression & 15172.37 & 5 & 3034.476 & 4.321 & $0.024^{*}$ \\
Residual & 7022.38 & 10 & 702.239 & & \\
Total & 22194.76 & 15 & & & \\
\hline
\end{tabular}

$\mathrm{SOV}=$ Source of variance, $\mathrm{SS}=\mathrm{Sum}$ of squares, $\mathrm{DF}=$ Degree of freedom, $M S=$ Mean square, $\mathrm{R}^{2}=$ $0.684, R=0.827$, Adjusted $R^{2}=0.525$, *Significant at $<0.05$

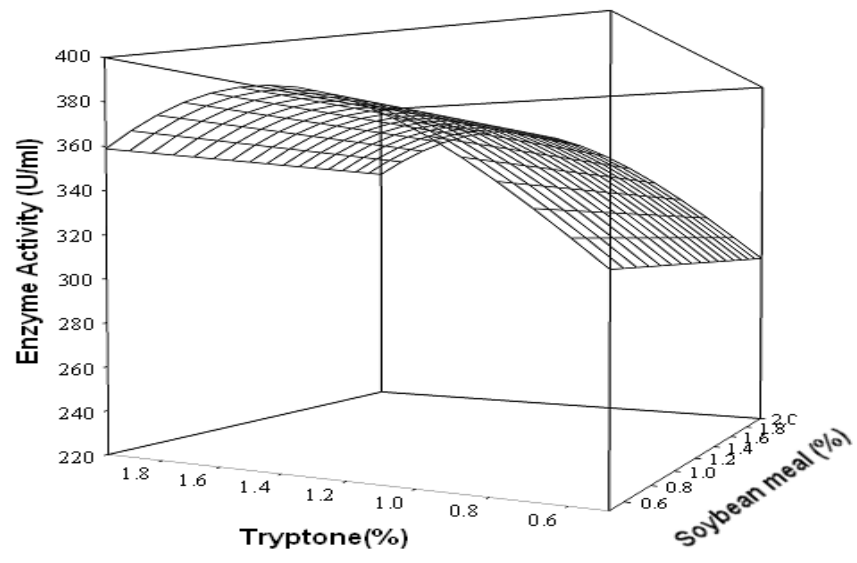

Figure 2. Three-dimensional graph of interaction of soybean meal and tryptone.

Ammonium sulphate precipitated protease from $P$. aeruginosa obtained was studied for the ability to hydrolyze different skin proteins with artificial substrates. Protease from $P$. aeruginosa showed highest activity against albuminous substrates followed by gelatin, elastin and haemoglobin. Albumin and haemoglobin hydrolysis showing the degradation of aluminous and blood protein adhered to the hide during slaughtering. From leather industry point of view present protease was found to be inactive against keratin and collagen substrates (Table 3). Non-keratinase activity showed hair saving and recovered hair may have application as a byproduct for production of synthetic fibers, biogas production, foaming agent for fire extinguishers, while hydrolyzed hair is used as agricultural fertilizer, soil conditioner, compost, additive in chrome tanning or retanning processes, animal/ poultry feed and also for production of cosmetics, pharmaceuticals and amino acid like cysteine (Thanikaivelan et al. 2004). Leather is nothing but a collagen and non collagenolytic protease activity produced undamaged and high quality leather with higher strength.

Table 3. Enzyme activities against different hide proteins.

\begin{tabular}{|ll|}
\hline Protein substrates & Enzyme activity $\left(\mathbf{U} \mathbf{~ L L}^{-1}\right) \pm$ SD \\
\hline Casein & $2427 \pm 201$ \\
BSA & $773 \pm 102$ \\
Gelatin & $698 \pm 52$ \\
Elastic- orcein & $8 \pm 0.95$ \\
Haemoglobin & $8 \pm 0.33$ \\
Keratin azure & 00 \\
Collagen & 00 \\
\hline
\end{tabular}

\section{Enzymatic Soaking}

Dry hide and skin require longer period of soaking for complete rehydration. To minimize the soaking time, enzymes have an important role. The hide pieces were soaked in water bath with different enzyme concentrations and were observed periodically for its water holding capacity as well as the softening of the hide. Table 4 , is showing increase in $\%$ moisture content of the buffalo hide as the enzyme concentration increased from $0.1-0.5 \%$. This increase in $\%$ moisture was due to the hydrolysis of the proteins especially globular proteins present in hide. The complete softening of buffalo hide was observed at 16-18 h. Similarly, soaking time of $20 \mathrm{~h}$ was observed with $1 \%$ acid proteinase from Rhizopus rhizopodiformis and sodium bisulphite (Kamini et al., 1999). Puvankrishnan and Dhar (1988) reported that a period of 36-48 $\mathrm{h}$ was necessary to wet back dry hides. Three commercial bacterial alkaline protease preparations were also studied for soaking of salted cow hides (Kamini et al., 1999). Thus, use of hydrolytic enzymes (protease, amylase) results in a decrease in soaking time, clean pelt and hydrolysis of unwanted proteins.

Table 4. Effect of enzyme concentrations on soaking

\begin{tabular}{|ll|}
\hline Soaking conditions & \% Moisture \\
\hline Tap water & 29.61 \\
Enzyme $0.1 \%$ & 57.26 \\
Enzyme $0.3 \%$ & 67.24 \\
Enzyme $0.5 \%$ & 84.37 \\
\hline
\end{tabular}

Soaked pieces were dehaired using lime-sulfide method and the L.S. of dehaired pelts are shown in Figure 3. Enzymatic soaking allows the loosening of scud, initiate 
opening of the fiber. As per earlier reports it also improved the softness and elasticity of rabbit skin and increased the area of fur (Puvankrishnan and Dhar, 1988). The soaked hide pieces showed empty follicles whereas the control piece showed disintegrated hair follicles. Thus, soaking help for dehairing operation of leather processing which reduces the need for dehairing chemicals by $30-60 \%$ (Nielsen, 2006).

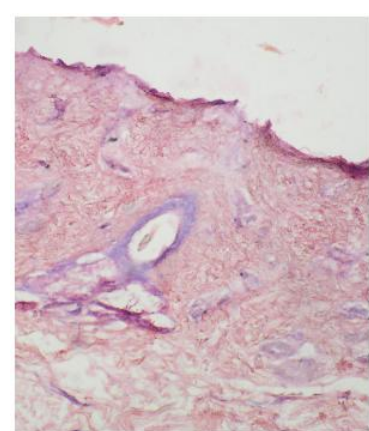

Control- Tap water (A)

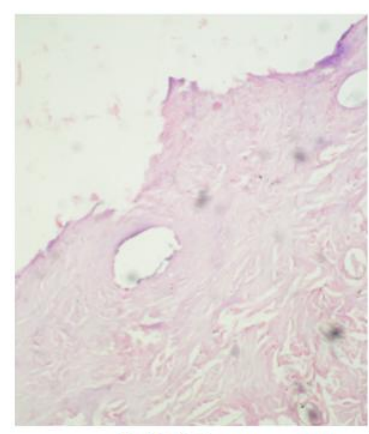

$0.3 \%$ Enzyme (C)

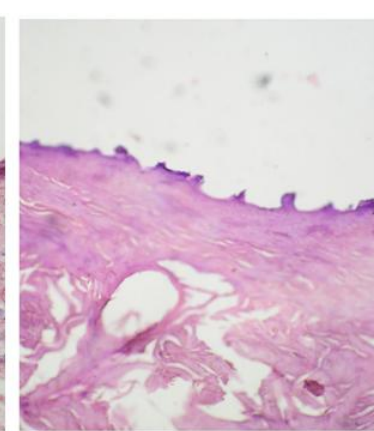

$0.1 \%$ Enzyme (B)

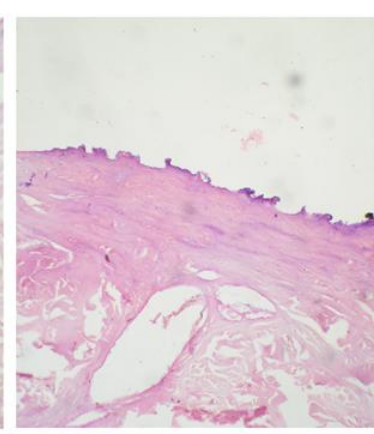

$0.5 \%$ Enzyme (D)
Figure 3. Micrographs of dehaired pelts soaked with A: tap water-control, B: $0.1 \%$ enzyme and C: $0.3 \%$ enzyme, D-0.5\% enzyme of $P$. aeruginosa MCM B-327 (A showed disintegrated hair follicles, B to D showed empty follicles and well opened collagen fibers).

\section{CONCLUSION}

The protease from $P$. aeruginosa has a property to hydrolyze unnecessary skin proteins for the production of collagen stabilized leather. Application of enzyme during soaking reduced the soaking time, promoted hair loosening, and assisted dehairing process by minimizing the use of chemicals.

\section{REFERENCES}

Adinarayana K, Ellaiah P (2002) Response surface optimization of critical medium components for the production of alkaline protease by a newly isolated Bacillus sp. Journal of Pharma and Pharmaceutical Science 5: 272- 278.

Chauhan B, Gupta R (2004) Application of statistical experimental design for optimization of alkaline protease production from Bacillus $\mathrm{sp}$. RGR-14. Process Biochemistry 39: 2115-2122.

Dutta JR, Dutta PK, Banerjee R (2005). Modeling and optimization of protease production by a newly isolated Pseudomonas sp. using a genetic algorithm Process Biochemistry 40: 879-884.

John DB, Merriline $J$ (2002) Theory and practice of histopathalogical techniques. $5^{\text {Th }}$ Edition. Churchill Publishing Company.

Kamini NR, Hemachander C, Geraldine J, Mala S, Puvanakrishnan R (1999) Microbial enzyme technology as an alternative to conventional chemical in leather industry. Current Science 77: 80-86.

Kanagraj J, Velappan KC, Chandra Babu NK, Sadulla S (2006) Solid waste generation in the leather industry and its utilization for cleaner environment- a review. Journal of Scientific and Industrial Research 65: 541- 548.

Luthra YK (2006) Indian leather industry. Leather Age March: 69-71.

Muthian PL, Ramanathan N, Nayudamma Y (1968) Biochemical studies of the skin samples obtained from different sites on various animals. Journal of American Leather Chemists Association 63: 38-47.

Nielsen PH (2006) Environmental assessment of enzyme application in the tanning industry. Leather International August- September: 18-24.

Puri S, Beg QK, Gupta R (2002) Optimization of alkaline protease production from Bacillus $\mathrm{sp}$. by response surface methodology. Current Microbiology 44: 286-290.

Puvankrishnan R and Dhar SC (1988). Enzymes in soaking, dehairing, bating and degreasing. In: Enzyme Technology in Beamhouse Practice. Central Leather Research Institute, Madras.

Rao YK, Lu SC, Liu BL and Tzeng YM (2006). Enhanced production of an extracellular proteasefrom Beauveria bassiana by optimization of cultivation processes. Biochemical Engineering Journal 28: 57-66.

Reddy LVA, Wee Y-J, Yun J-S, Ryu H-W (2008) Optimization of alkaline protease production by batch culture of Bacillus sp. RKY3 though Plackett-Burman and response surface methodological approaches. Bioresource Technology 99: 2242-2249. 
Sachar LA, Winter KK, Sicher N, Frankel S (1995) Photometric method for estimation of elastase activity. Proceeding of Society of Experimental Medical Biology 90: 323-326.

Sarath G, Motte RSDL, Wagner FW (1996) Hemoglobin hydrolysis assay. In: Proteolytic Enzymes- A Practical Approach, Beynon RJ, Bond JS (Eds). Oxford IRL Press, New York.

Sharphouse JH (1983) Leather Technician's Handbook. $2^{\text {nd }}$ Edn. Leather Producers Association, London.

Takami H, Akiba T, Horikoshi K (1990) Characterization of an alkaline protease from Bacillus sp. No. AH- 101. Applied Microbiology and Biotechnology 33: 519- 523.

Thanikaivelan P, Rao JR, Nair BU and Ramasami T (2003). Approach towards zero discharge tanning: role of concentration on the development of eco-friendly liming- reliming process. Journal of Cleaner Production 11:79- 90.

Saxena R, Singh R (2010) Statistical optimization of conditions for protease production from Bacillus sp. Acta Biologica Szegediensis 54 (2): 135-141.

Woessner JF (1961) The determination of hydroxyproline in tissue and protein samples containing small portions of this iminoacids. Archives in Biochemistry and Biophysics 93: 440- 447.

Zambare VP, Nilegaonkar SS, Kanekar PP (2011) Production optimization and purification of a novel extracellular protease from Pseudomonas aeruginosa MCM B-327. New Biotechnology 28 (2): 173-181.

Zambare VP, Nilegaonkar SS, Kanekar PP (2011a) Use of agroresidues for protease production and application in degelatinazation. Research Journal of BioTechnology 6(2): 62-65.

\section{AUTHORS}

\section{P. Zambare, PhD}

He is a General Manager at Sequence Biotech Pvt Ltd, Nasik, India. Dr. Vasudeo specializes in microbial enzymes, extremophiles, renewable energy (biomass, biofuels and bioenergy), antimicrobial peptides and biodegradable plastic for biomedical applications. In his research career, he published several research articles, book chapters, abstracts in conferences, patents filed. Recently, he is honoring as associate editor, technical editor, advisory board member and editorial board member for more than 70 International research journals.

\section{S.S. Nilegaonkar, PhD}

She has been working as Scientist D, in MACS-Agharkar Research Institute, Pune, M.S. India. Working in field of biotechnology, especially in microbial production of industrially important compounds, enzymes \& their inhibitors, development processes for enrichment of functional foods. She is a current Fellow-member of the International Society of Biotechnology (India).Research Publications > 30, Chapters 2, Books 1, Patents Indian - one sealed two filed, patent-US/German filed one.

\section{P.P. Kanekar, PhD}

She has been working as an Emiratous Scientist at Microbial Sciences Division of MACS-Agharkar Research Institute, Pune, M.S., India. She has post-doctoral research experience of 30 years since 1980 . Her main areas of interest are 1.Biodegradation and bioremeadiation of toxic organic pollutants, 2. Microbial diversity and conservation of bacteria and archae, 3. Biotechnological potential of extremophiles. So far 12 students have been awarded Ph.D.degree in the subject of Microbiology of Pune University and six students are registered for Ph.D. degree, 51 papers are published in peer reviewed journals, 4 Indian patents are granted, 3 patents applied and one technology transferred for commercialization.

\section{UILIS D-Sule}

This journal is published by the University Library System of the University of Pittsburgh

as part of its D-Scribe Digital Publishing Program, and is cosponsored by the University of Pittsburgh Press. 